APP-33 精栄腫瑒における peroxisome proliferator activator-receptors (PPAR) $-\gamma$ の発現

\begin{abstract}
大阪市立大学院 医学研究科 泌尿器病態学
吉村力勇, 長谷 太郎, 松山 昌秀, 颉川 良浩, 三橋誠 土田 健司, 和田 誠次, 仲谷 達也

目的)近年種々の腫瘍組織においてPPARー $\gamma$ が瓷く発現している 事、またそのアコニストを投与する事により腫蓩細胞の発有を抑制 したり、アポトーシスに陥るという報告がなされている。今回我々

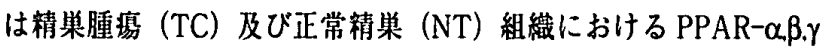
の発現を検討した。(方法)TC 72 例、NT 20 例を対象とし、PPARs の mRNAを検討するためRT-PCR 、PPARsの発現ならびに局在 を検討するため組織免疫染色を行い検討した。結果了TC 72 例中単 一組織であったものは 58 例、 2 種以上の組織を含んだものは 14 例、 各組織型は Seminoma31 例、 embryonal carcinoma8 例、yolk sac tumor7 例、 choriocarcinoma7 例、 teratoma5 例であった。 RT.PCR では、PPAR- $\alpha \beta$ は全ての組織型の TC 及びNT で明らかなバンド の発現を認めたが、PPARー $\gamma$ はT ではバンドの発現は認められな かったが、TCでは全ての組織型で强いバントの発現を認めた。組織 免疫染色でも同様に PPAR- $\alpha \beta$ は NT を含む全ての組織で発現が 認められたが、PPARー $\gamma$ はT ではほとんどその発現が認められな かったのに对して、TCでは全ての組織型腫痛において腫晹細胞、血 管に強い発現を認めた。[考察] PPAR一 $\gamma$ は他の腫堭と同樣に精巣腫 湟においても深く関わっていることが示された。この事はPPARー $\gamma$ のアゴニストを用いた新たな精巣腫湟治療の可能性が期待される。
\end{abstract}

\section{APP-34 脊蹃梗塞を発症した透析患者の一例}

\section{PL 病院 泌尿器科" PL病院 神経内科" 大阪市立大 学医学部泌尿器病態学 ${ }^{3)}$}

葉山 环磨”, 青山 真人”, 中村 敬弘", 飯盛厷記"

川村 正喜", 八木 祐吏 ${ }^{21}$, 武本 佳昭 ${ }^{3}$, 仲谷 達也 ${ }^{31}$

患者は 62 歳、男性。慢性腎不全にて平成 6 年より腹膜透 析導入。平成 12 年に腹膜機能低下のため、血液透析へ移 行し、週 3 回透析を行っていた。平成 14 年 5 月 5 日、下 肢しびれが出現。5月 7 日に背部痛、両下肢麻瘦を認め た。5月 8 日に当院受診し、精查加療目的にて入院となっ た。血圧は $200 / 120 \mathrm{mmHg}$ 、意識清明、排便、排尿障害あ り。神経学的所見では、左㑡胸部以下の知営障害があり、 握力は右が $30 \mathrm{~kg}$ 、左が $6 \mathrm{~kg}$ であった。媣部腱反射は、左 膝蓋腱反射及び腓腹笳腱反射の穴進を認めた。神経内科 にて、下部頝㔠レベルに病変が有るとの診断を得、MRI 検查を行なった。経過からみて脊娟梗塞の可能性が高く、 早期リハビリ開始となった。しびれは残るものの、5月 11 日より左下肢の膝たてが、 5 月 21 日には杖歩行が可能 となり、5月 26 日退院となった。6月12日のMRIにて、 第 7 頝椎レベルの、脊㵦中心部やや左㑡よりに $\mathrm{T} 2$ 强調 像にて、 high intensity line を認めた。 Retrospective では

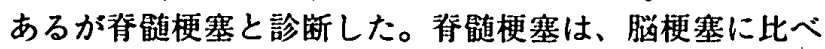
て稀な疾患である。文献的考察を加え報告する。
APP-35

ブラッドアクセスの管理と評価一上腕 動脈穿刺によるシャント造影と超音波 高速 3 次元表示画像

\author{
東京女子医科大学 腎藏病維合医痖センター 泌尿器科 \\ 戸田紊子
}

【緒言】血液透析患者においては高齢化, 䌅尿病患者の增 加により，使用するアクセス血管の閒塞や狭窄が臨床的 に大きな問題となっている．近年，バルンカテーテルを 用いた経皮的血管形成術（PTA）が飛躍的に進歩してい る.【対象と方法】当科ではブラッドアクセス管理の一法 として高速 3 次元表示 (Vol-mode) によるシャント肢前 腕の超音波検査 (3DUS) を施行している。あらかじめ 3 DUS を施行し狭窄等の疑われた症例に対し，上腕動脈穿 刺による血管造影 (IA-DSA) を施行した.【結果】13 症例 にIADSAをのべ 16 回施行した。造影と同時に確認され た狭䇤部に対し，13 回のPTAを試みた. 2 例は狭窄が高 度でガイドワイヤーが通過しなかったが，他の庭例は良 好に狭窄部を拡張し得た。合併症として上腕動脈呀刺部 の血腫を 1 例に認めた.【結語】3DUSは,極めて短時間で 非侵椠的に反復した画像診断が可能であり，スクリーニ ングとして，ブラッドアクセス管理に有用であった。加 えて, 吻合部ないし動脈側の狭害した内シャント不全に 対し，IA-DSA 時にPTA を併用した治療は大变有効で あると思われた。

\section{APP-36 ラットFK506 慢性腎海性モデルにおけ る NF- $\mathrm{KB}$ の役哰}

大阪市立大学 大学院医学研究科 泌尿器病態学" 大 阪市立大学 大学院医学研究科 薬効安全性学 ${ }^{2}$ 玉田 聡", 浅井 利大", 田代 孝一郎", 内田 潤次" 杉村一誠", 三浦 克之"), 仲谷達也"

【目的】 NF-KBの活性化は各種炎症性疾患に重要な役割を担って いる。今回の実験では免疫抑制薬 Tacrolimus（FK506）による慢 性腎䇤性における NF- $\mathrm{KB}$ の関与を検討した。【方法】実験的 cyclosporine A P FK506による慢性腎障害は減塭食下で促進する ことが知られている。そこで雄性 SD ラットを低 $\mathrm{Na}$ 食にて飼育 し、FK506を $1 \mathrm{mg} / \mathrm{kg} / \mathrm{day}$ の割合で 42 日連日皮下投与し、慢性 婜障害を惹起した。一方、NF- $\mathrm{kB}$ の役割を検討する目的でその阻 害薬である Pyrrolidine Dithiocarbamate (PDTC)を経口投与 (100 および $200 \mathrm{mg} / \mathrm{kg} /$ day) L、FK506 堅障害に对する効果を検討し たNF- $\mathrm{KB}$ の DNA 結合活性は EMSA で評価した。マクロファー シの浸洞は抗 ED-1 抗体を用いて免疫染色し、その颃性緗胞数を 単位面稓あたりで評価した。成絧】FK506 投与によりp50,p65 の subunitより粠成された NF- $\mathrm{KB} の \mathrm{DNA}$ 結合活性は 3 倍に增 加した。腎間質においてマクロファージ没潤が著明に增加し、腎 間芹の縞状線維化が钼察された。PDTC 投与により NF- $\mathrm{kB}$ 、マク ロフフージの浸閏は滔度依存性に抑制され、特に $200 \mathrm{mg}$ 投与群 は vehicle 投与群レべルにまで抑制された。また、腎間斦の線維化 はPDTC 投与により有意に抑制された。(結詥)FK506による慢

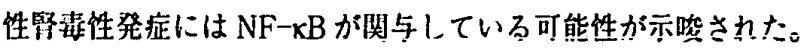

